7. Reprod. Fert. (1968) 15, 259-266

\title{
MOUSE HYPERAEMIC CORPORA LUTEA ASSAY OF PROLACTIN
}

\author{
N. KOVACIC* \\ National Institute for Medical Research, Mill Hill, London
}

(Received 6th February 1967)

\begin{abstract}
Summary. A method for the estimation of the biological activity of prolactin has been developed based on the induction of hyperaemia of corpora lutea of ovulation in 3- to 4-month-old non-parous mice of the Parkes strain. Mice were treated with prolactin for 3 days starting on the lst day of di-oestrus and the ovaries inspected in situ for hyperaemic corpora lutea on the 4th day of the experiment. The development of hyperaemic corpora lutea of ovulation in response to prolactin was found to be a quantal effect and linearly related to the dose. The slope of the dose response curves was highly significant. The assay appears to be specific for prolactin.

The activity of ovine prolactin NIH-P-s7 was $19.6 \mathrm{i} . \mathrm{u} . / \mathrm{mg}$. Seven batches of human pituitary growth hormone, prepared according to the method described by Raben (1959), of the Medical Research Council, all contained prolactin activity and the estimated potency varied from 2.6 to 14.9 i.u./mg. The activity of a preparation of human placental lactogen from the Lederle Laboratories was $2 \cdot 9$ i.u./mg.

Ovaries of mice treated with ovine prolactin, human growth hormone and human placental lactogen appeared like the ovaries of mice in early pregnancy or pseudopregnancy.
\end{abstract}

\section{INTRODUCTION}

It has been shown that only prolactin induces and maintains the activity of the corpora lutea of ovulation in hypophysectomized adult mice (Kovacic, 1964). However, the corpora lutea of ovulation also remain inactive during the short oestrous cycle in normal mice, unless treated with prolactin, which suggests that the pituitary gland does not release the hormone (Kovacic, 1965). Normal mice are, therefore, suitable test animals for the biological assay of prolactin.

The aim of this paper is to describe a method of assay of the biological activity of prolactin using hyperaemic corpora lutea in non-parous mice as the parameter.

Animals

\section{MATERIALS AND METHODS}

Virgin female mice of the Parkes strain, 3 to 4 months old, were used for the

* Present address: Department of Clinical Endocrinology, The Birmingham and Midland Hospital for Women, Sparkhill, Birmingham. 
experiments. The weight of mice was 24 to $31 \mathrm{~g}$ (mean $29 \mathrm{~g}$ ). The length of the oestrous cycle varies among mice due mainly to variation in the duration of di-oestrus, but each mouse has its own characteristic cycle in young adulthood. For the biological assay of prolactin, mice were used which had regular cycles and short di-oestrous periods, i.e. mice with at least three consecutive oestrous cycles of 4 to 5 days duration. The oestrous cycle was examined by daily reading of the vaginal smears. A stock of 180 mice was maintained by regular replacement and was sufficient to provide enough animals at the right stage of the oestrous cycle for two to three assays of prolactin a week. The remaining mice were used during the following weeks on the first day of di-oestrus.

\section{Technique of assay}

Mice were treated with prolactin from the 1st day of di-oestrus for 3 consecutive days. The total dose of prolactin for each animal was contained in $1 \cdot 2$ $\mathrm{ml}$ of distilled water ( $\mathrm{pH}$ adjusted to 8.0), and divided into three equal doses and injected subcutaneously once daily. The animals were killed with chloroform on the 4th day of the experiment and the ovaries examined in situ for hyperaemic corpora lutea, using magnifying eye-glasses if necessary.

Corpora lutea of ovulation are situated in the cortical zone of the ovary and can be seen on its surface as distinct globules. Inactive corpora lutea are pale. In contrast, active corpora lutea are hyperaemic, large and easily recognized as bright red globules protruding on the surface of the ovary. The ovary usually contains three or four fresh corpora lutea of ovulation, but their number may vary between one and five. Accordingly, in a positive response to prolactin, one to five hyperaemic corpora lutea were found. In most mice, both ovaries responded equally, but there were cases when hyperaemic corpora lutea were found unilaterally. The response of individual corpora lutea of ovulation to prolactin, thus, appears to be a quantal effect. Hyperaemic corpora lutea are distinguishable from haemorrhagic follicles which appear as dark red dots and are seldom found in untreated adult mice.

In the prolactin assay mice were treated at two to four dose levels each of the unknown and the reference preparation and the interval between the doses was equal to $\log _{10} 2$. The doses of prolactin/mouse were from 0.4 to 1.6 i.u., i.e. between 19 and $75 \mu \mathrm{g}$ of the Second International Standard for Prolactin. Five mice were used per dose and all ovaries examined. In each group the ovaries were counted which contained hyperaemic corpora lutea. The results were calculated by the method of the parallel lines using the probit transformation of the percentage of the positive responses as described by Finney (1952).

\section{Specificity of the assay}

In studies on the specificity of the mouse hyperaemic corpora lutea assay the effect of prolactin was compared with the effects of human luteinizing hormone, human chorionic gonadotrophin, pregnant mares' serum gonadotrophin, bovine growth hormone and adrenocorticotrophic hormone. The design of the experiments was similar but the number of the dose levels varied from one to six. Five to seven mice were treated/dose level of the preparation. 
The effects of ovine and bovine luteinizing hormones upon the mouse ovaries were also studied, but the animals were treated for 5 days and the ovaries examined on the 6 th day.

In all groups, the ovaries were inspected for their size and the appearance of corpora lutea.

\section{Preparations assayed in terms of the Second International Standard for Prolactin}

The hormones which were assayed by the hyperaemic corpora lutea method are listed below. The list includes ovine prolactin, human pituitary growth hormone and human placental lactogen. All samples of human pituitary growth hormone were prepared by Raben's (1959) method.

The potency of the preparations of human growth hormone was estimated by $\operatorname{Dr} \mathrm{M}$. Stack-Dunne using the growth promoting assay in hypophysectomized rats (personal communication).

(1) The Second International Standard for Prolactin (ovine prolactin), potency 22 i.u./mg.

(2) Prolactin (ovine), NIH-P-s7, potency $24 \cdot 3$ i.u./mg.

(3) Human pituitary growth hormone (HGH) R4, MRG, potency $0.72 \mathrm{i} . \mathrm{u} . / \mathrm{mg}$ (0.52 to 1.02$)$.

(4) HGH R7, MRC, potency 0.56 i.u./mg (0.43 to 0.73$)$.

(5) HGH R8, MRG, potency 0.62 i.u./mg (0.40 to 0.94$)$.

(6) HGH R9, MRC, potency 1.21 i.u./mg (1.03 to 1.42 ).

(7) HGH R10D, MRC.

(8) HGH R10C, MRG.

(9) HGH R10E, MRC.

The combined result of the preparations (7), (8) and (9) is 1.16 i.u./mg (0.91 to $1 \cdot 48)$.

(10) Human placental lactogen, Lederle Laboratories, New York, prepared by Dr P. Bell.

Preparations used in a study of the specificity of the mouse hyperaemic corpora lutea method

The following list includes the preparations of the hormone which were used in the study of the specificity of the method. It comprises luteinizing hormones, pregnant mares' serum gonadotrophin, bovine growth hormone and adrenocorticotrophin.

(11) Human pituitary luteinizing hormone (HLH), DEAE-I (2nd February 1966), potency $2 \cdot 4 \mathrm{mg}$ NIH-LH-sl $/ \mathrm{mg}$.

(12) HLH, DEAE-I (18th April 1966), potency $3.6 \mathrm{mg} \mathrm{NHH-LH-s1/mg.}$

(13) HLH, DEAE-II (18th April 1966), potency $0.8 \mathrm{mg}$ NIH-LH-sl/mg. Human pituitary luteinizing hormone was prepared by $\mathrm{Dr}$ A. S. Hartree, see Hartree (1966). The potency was estimated by the immuno-assay.

(14) The Second International Standard for chorionic gonadotrophin, potency 5300 i.u./ampoule.

(15) Ovine pituitary luteinizing hormone, NIH-LH-s10, potency $0.98 \mathrm{i} . \mathrm{u} . / \mathrm{mg}$ $(0.88$ to 1.08$)$.

(16) Bovine pituitary luteinizing hormone, NIH-LH-B3, potency $1.02 \mathrm{i} . \mathrm{u} . / \mathrm{mg}$ $(0.77$ to 1.32$)$. 
The potency of ovine and bovine luteinizing hormones was estimated by the ovarian ascorbic acid depletion method (Endocrinology Study Section, NIH, USA).

(17) The Second International Standard for serum gonadotrophin, potency 1600 i.u./ampoule.

(18) International Standard for growth hormone (of bovine origin), potency 1 i.u./mg.

(19) Bovine growth hormone, NIH-GH-B10, potency $1 \cdot 12$ i.u./mg $(0.86$ to $1 \cdot 45)$.

The potency of bovine growth hormone was estimated by the body-weight gain method in hypophysectomized rats (Endocrinology Study Section, NIH).

(20) The Third International Standard for corticotrophin, 1962, potency 5 i.u./ampoule.

The figures in parentheses represent the $95 \%$ confidence limits of the results.

\section{RESULTS}

\section{Control mice}

The sixty mice used as the control animals were injected with distilled water as described in the technique of the assay. A total of 120 ovaries was inspected and hyperaemic corpora lutea found in five ovaries only $(4 \cdot 16 \%)$. This was due to spontaneous occurrence of pseudopregnancy.

\section{Assay of prolactin}

Table 1 shows the results of assays of ovine prolactin, NIH-P-s7, preparations of human pituitary growth hormone and human placental lactogen by the mouse hyperaemic corpora lutea method. It will be noticed that the activity of ovine prolactin NIH-P-s7 was estimated to be $19.6 \mathrm{i} . \mathrm{u} . / \mathrm{mg}$ which is similar to the results obtained by the pigeon crop gland assay as specified by the Endocrinology Study Section, NIH, U.S.A. All preparations of human pituitary growth hormone had prolactin activity and the estimate varied from 2.6 to $14.9 \mathrm{i} . \mathrm{u} . / \mathrm{mg}$. The estimate of potency of human placental lactogen (from Lederle Laboratories) was $2.9 \mathrm{i} . \mathrm{u} . / \mathrm{mg}$. The $95 \%$ fiducial limits of the results were within a reasonable range in all assays. The common slope (b) of the dose response curves was highly significant in most assays $(P=\sim-0.001$ or $<0.001)$ and there was no deviation from parallelism $(P>0 \cdot 1)$. Deviation from linearity occurred in one assay of human growth hormone.

\section{Specificity of the assay}

Human pituitary luteinizing hormone. The preparation of human pituitary luteinizing hormone, DEAE-I (18th April 1966) was tested at 40 and $80 \mu \mathrm{g} / \mathrm{mouse}$ and the preparation, DEAE-II (18th April 1966) at $200 \mu \mathrm{g} /$ mouse. A third preparation of human pituitary luteinizing hormone, DEAE-I (2nd February 1966) was also assayed at a dose of $200 \mu \mathrm{g} /$ mouse. A total of forty-four ovaries was examined. The ovaries were diffusely hyperaemic and enlarged two to three times. Corpora lutea were pale and of various size, ranging from normal to very small and in some ovaries they were absent. Hyperaemic corpora 
lutea were present in two ovaries $(4.56 \%)$. In contrast, haemorrhagic follicles were frequently found.

Human chorionic gonadotrophin (International Standard). This produced similar effects as human pituitary luteinizing hormone. The preparation was tested at five dose levels between 8 and 128 i.u./mouse. Fifty ovaries were examined and hyperaemic corpora lutea found in three $(6 \%)$.

Ovine luteinizing hormone, $\mathrm{NIH}-\mathrm{LH}-\mathrm{S10}$, and bovine luteinizing hormone, $\mathrm{NIH}-\mathrm{LH}-$ $B 3$. These were assayed at $0.5,1.0$ and $2.0 \mathrm{mg} /$ mouse. Sixty-eight ovaries were inspected. Corpora lutea were mostly of normal size and pale and hyperaemic

TABLE 1

RESUlTS OF ASSAYS OF THE PREPARATIONS BY THE MOUSE HYPERAEMIC CORPORA LUTEA TEST OF PROLACTIN

\begin{tabular}{|c|c|c|c|c|c|c|c|c|}
\hline \multirow[b]{2}{*}{ Preparation } & \multirow[b]{2}{*}{$\begin{array}{c}\text { Assay } \\
\text { No. }\end{array}$} & \multirow[b]{2}{*}{ Design } & \multirow{2}{*}{$\begin{array}{c}\text { Relative } \\
\text { potency } \\
\text { (i.u./mg) }\end{array}$} & \multirow{2}{*}{$\begin{array}{l}95 \% \\
\text { fiducial } \\
\text { limits }\end{array}$} & \multirow{2}{*}{$\begin{array}{c}\text { Common } \\
\text { Slope } \\
(b)\end{array}$} & \multicolumn{3}{|c|}{ Validity tests } \\
\hline & & & & & & $\begin{array}{c}\text { Significance } \\
\text { of slope } \\
P\end{array}$ & $\begin{array}{c}\text { Parallelism } \\
P\end{array}$ & $\underset{P}{\text { Linearity }}$ \\
\hline$\left\{\begin{array}{c}\text { Prolactin* } \\
\text { (ovine) } \\
\text { Nm-P-s7 }\end{array}\right.$ & $\begin{array}{l}1 \\
2\end{array}$ & $\begin{array}{l}2: 2 \\
3: 3\end{array}$ & $\begin{array}{l}16 \cdot 7 \\
25 \cdot 4\end{array}$ & $\begin{array}{r}8.4 \text { to } 18.6 \\
13.9 \text { to } 49.9\end{array}$ & $\begin{array}{l}4.94 \\
3.08\end{array}$ & $\begin{array}{c}0.01-0.001 \\
<0.001\end{array}$ & $\begin{array}{c}0.5-0.3 \\
\simeq 0.90\end{array}$ & $0.8-0.7$ \\
\hline HGH R4 & 1 & $3: 3$ & $2 \cdot 6$ & 1.7 to 3.6 & 6.58 & $<0.001$ & $0.3-0.2$ & $0.5-0.3$ \\
\hline HGH R7** & 1 & $3: 3$ & $4 \cdot 8$ & 3.1 to 7.2 & $4 \cdot 83$ & $<0.001$ & $0.7-0.5$ & $0.5-0.3$ \\
\hline & 2 & $2: 2$ & 3.9 & 2.5 to 5.4 & 8.06 & $<0.001$ & $0.8-0.7$ & - \\
\hline HGH R8 & 1 & $3: 3$ & $6 \cdot 3$ & 4.2 to 9.5 & 4.76 & $<0.001$ & $0.7-0.5$ & $0.05-0.02$ \\
\hline нон R9 & 1 & $4: 4$ & $13 \cdot 1$ & 6.8 to 28.2 & $2 \cdot 38$ & $<0.001$ & $0.95-0.90$ & $0.7-0.5$ \\
\hline HGHR $10 D^{* * *}$ & 1 & $3: 3$ & $11 \cdot 0$ & 6.6 to 18.3 & $4 \cdot 25$ & $<0.001$ & $>0.99$ & $0.9-0.8$ \\
\hline & 2 & $3: 2$ & $9 \cdot 7$ & 4.0 to 16.6 & $3 \cdot 35$ & $<0.001$ & $0.5-0.3$ & $0.5-0.3$ \\
\hline HGH R10G & 1 & $3: 3$ & 14.9 & $7 \cdot 4$ to 38.8 & $2 \cdot 48$ & $\simeq 0.001$ & $0.9-0.8$ & $0.7-0.5$ \\
\hline HGH RIOE & 1 & $3: 2$ & 5.5 & 3.7 to 8.1 & 6.49 & $<0.001$ & $0.7-0.5$ & $0.8-0.7$ \\
\hline $\begin{array}{l}\text { Human } \\
\text { placental } \\
\text { lactogen }\end{array}$ & 1 & $3: 3$ & $2 \cdot 9$ & 1.7 to 4.8 & $3 \cdot 89$ & $<0.001$ & $0.3-0.2$ & $0.99-0.98$ \\
\hline
\end{tabular}

Results expressed in terms of the Second International Standard for Prolactin, potency $22 \mathrm{i} . \mathrm{u} . / \mathrm{mg}$. Index of precision $(\lambda)=1 / b$.

* NIH-P-s7: combined result $=19.6$ i.u. $/ \mathrm{mg}(95 \%$ confidence limits 13.9 to $27 \cdot 6)$.

** HGH R7: combined result $=4 \cdot 2 \mathrm{i} . \mathrm{u} . / \mathrm{mg}$ (95\% confidence limits 3.3 to $5 \cdot 3$ ).

*** HGH RIOD: combined result $=10.5 \mathrm{i}$.u./mg (95\% confidence limits 7.3 to 14.9 ).

corpora lutea were found in two ovaries only $(2.94 \%)$. The ovaries were slightly enlarged.

Pregnant mares' serum gonadotrophin (Second International Standard). The preparation was tested at six dose levels between 1.5 and 50 i.u./mouse and sixty-four ovaries were examined. The ovaries became enlarged at the dose of 3 units. In general, the ovaries were three to four times the normal size and diffusely hyperaemic. Corpora lutea were pale and of various size and were absent in some ovaries. Hyperaemic corpora lutea were found in four ovaries $(6 \cdot 25 \%)$. 
Bovine growth hormone. Bovine growth hormone, NIH-GH-B10, was tested at a dose of $1.2 \mathrm{mg} /$ mouse and the International Standard for growth hormone (of bovine origin) at 1.2 and $2.4 \mathrm{mg} /$ dose levels. Forty ovaries were examined and hyperaemic corpora lutea found only in two $(5 \%)$. The ovaries were of the normal size and resembled those of the control group. In contrast, preparations of human pituitary growth hormone, mentioned earlier in this paper, activated maximally corpora lutea of ovulation at doses of 150 or $300 \mu \mathrm{g} / \mathrm{mouse}$.

Adrenocorticotrophic Hormone (Third International Standard) was assayed at 2 i.u./mouse. The hormone had no effect upon the mouse ovary. Five mice were used for this experiment.

\section{DISCUSSION}

In the mouse, prolactin is secreted during the first half of pregnancy (Deanesly $\&$ Newton, 1940-41) and in pseudopregnancy. However, in nulliparous mice there is no biological evidence that the pituitary gland releases prolactin during the oestrous cycle of 4 to 5 days duration, and these animals are, therefore, suitable for the assay of prolactin (Kovacic, 1965). In this species prolactin has two primary biological effects: luteotrophic and lactogenic, and two secondary effects: the formation of deciduomata in the uterus and the alveolar growth of the mammary glands. The secondary effects depend upon the normal function of the corpora lutea of ovulation.

In the present work, the biological activity of prolactin was measured, using the direct effect of the hormone upon the corpora lutea of mice of the Parkes strain. Activated corpora lutea are hyperaemic and represent a clear-cut endpoint for reading the results. The oestrous cycle differs between individual mice and the animals must be selected carefully in order to achieve the uniformity of experimental conditions. Mice with an oestrous cycle of 4 to 5 days length were used for all experiments and this ensured a reasonable precision of the assay and good reproducibility of the results. Spontaneous pseudopregnancy and the concomitant hyperaemia of corpora lutea occurred in $4 \cdot 16 \%$ of the control ovaries. This incidence is apparently so low as not to influence unduly the effect upon the common slope of the dose-response curves which was highly significant in most assays.

The hyperaemic corpora lutea assay of prolactin appears to be specific. Prolactin activity was detected in preparations of human pituitary growth hormone and human placental lactogen, but not in preparations of bovine growth hormone. The slopes of the dose response curves of the preparations of human pituitary growth hormone and human placental lactogen were similar and parallel to that of ovine prolactin.

Pituitary luteinizing hormones of human, ovine and bovine origin, HCG and PMSG did not induce hyperaemia of corpora lutea greater than observed in the control group, i.e. between 2.94 and $6.25 \%$. This suggests that the occurrence of hyperaemic corpora lutea in mice treated with luteinizing hormone or PMSG was due to spontaneous pseudopregnancy rather than to the luteotrophic activity of these hormones. The incidence of hyperaemic corpora lutea in mice treated with bovine growth hormone was also similar to that of the control group, i.e. it was $5 \%$. 
However, in a previous work it was reported that preparations of human pituitary luteinizing hormone, HCG and PMSG produced a higher incidence of ovaries showing hyperaemic corpora lutea than occurred in the control group (Kovacic, 1966a). This was not due to contamination of the preparations with prolactin because the same hormones did not have a similar effect in hypophysectomized mice. This finding could tentatively be explained by the effect of these hormones upon the release of endogenous prolactin in this particular strain of mice.

The sensitivity of the present method is higher than that of the mouse deciduoma assay (Kovacic, 1965) and similar to the rabbit intraductal lactogenic test for prolactin. It is, however, lower than the local pigeon crop gland method (Folley, personal communication).

The ovaries of mice treated with prolactin or luteinizing hormone differ. The ovaries of mice injected with ovine prolactin or preparations of human growth hormone or human placental lactogen are indistinguishable from the ovaries in early pregnancy or pseudopregnancy. The corpora lutea are hyperaemic and luteal cells enlarged but interstitial cells show no signs of stimulation (Kovacic, 1965). In contrast, the ovaries of mice treated with luteinizing hormone are artificial products and they are enlarged by the excessive growth of interstitial cells. Such growth of interstitial cells never occurs in normal mice. However, corpora lutea tend to regress in the majority of these animals probably because of the lack of the secretion of prolactin (Kovacic, unpublished results).

The results of the prolactin assays by the hyperaemic corpora lutea method of human pituitary growth hormone and human placental lactogen were lower than the results obtained by the rabbit lactogenic method but similar to or higher than the figures given by the pigeon crop gland assay (Forsyth, Folley \& Chadwick, 1965; Forsyth, 1967). Similar results of assays of human growth hormone and placental lactogen were obtained by the mouse deciduoma method (Hartree, Kovacic \& Thomas, 1965; Kovacic, 1966b). Mouse deciduoma method is, however, not specific for prolactin because luteinizing hormone also induces the decidual response in the injured uterus (Kovacic, 1964).

\section{ACKNOWLEDGMENTS}

This work was supported by a grant from the World Health Organization. My thanks are due to Professor A. E. Wilhelmi and the Endocrinology Study Section of the National Institutes of Health, Bethesda, U.S.A., for the generous gift of prolactin, ovine and bovine luteinizing hormones and bovine growth hormone, and to $\operatorname{Dr}$ A. Stockell Hartree from the University of Cambridge for the preparations of human pituitary luteinizing hormone. Human placental lactogen was prepared and kindly supplied by Dr P. Bell of the Lederle Laboratories, New York, U.S.A. Miss M. V. Mussett and Miss P. Woodward gave statistical analysis of the results. The technical assistance of $\mathrm{Mr} \mathrm{A}$. Jennings was appreciated.

\section{REFERENCES}

Deanesly, R. \& Newton, W. H. (1940-41) The influence of the placenta on the corpus luteum of pregnancy in the mouse. 7 . Endocr. 2, 317.

Finney, D. J. (1952) Statistical methods in biological assay. C. Griffin, London. 
Forsyth, I. (1967) Lactogenic and pigeon crop-stimulating activities of a human placental lactogen preparation. F. Endocr. 37, xxxv.

Forsyth, I., Folley, S. J. \& ChadWICK, A. (1965) Lactogenic and pigeon crop-stimulating activities of human pituitary growth hormone preparations. F. Endocr. 31, 115.

Hartree, A. Stockell, Kovacic, N. \& Thomas, M. (1965) Growth promoting and luteotrophic activities of human growth hormone. F. Endocr. 33, 249.

Hartree, A. Stockell (1966) Separation and partial purification of the protein hormones from human pituitary glands. Biochem. F. 100, 754 .

Kovacic, N. (1964) Biological characteristics of pituitary and placental hormones. F. Reprod. Fert. 8, 165.

Kovacic, N. (1965) Prolactin assay by the decidual reaction in the mouse. 7. Endocr. 33, 295.

Kovacrc, N. (1966a) Effects of prolactin, luteinizing hormone, human chorionic gonadotrophin or pregnant mares' serum gonadotrophin on corpora lutea of adult normal or hypophysectomized mice. F. Endocr. 34, v.

Kovacic, N. (1966b) Comparison of human placental lactogen and human pituitary growth hormone by the mouse luteotrophic assay. F. Endocr. 35, xxv.

Raben, M. S. (1959) Human growth hormone. Recent Prog. Horm. Res. 15, 71. 